\title{
Study of the aerobic biodegradation of coke wastewater in a two and three-step activated sludge process
}

\author{
I. Vázquez, J. Rodríguez, E. Marañón*, L. Castrillón, Y. Fernández \\ Department of Chemical and Environmental Engineering, Higher Polytechnic School of Engineering, University of Oviedo, 33204 Gijón, Spain
}

Received 14 September 2005; received in revised form 1 May 2006; accepted 2 May 2006

\begin{abstract}
A laboratory-scale biological plant composed of two aerobic reactors operating at $35^{\circ} \mathrm{C}$ was used to study the biodegradation of coke wastewater. The main pollutants to be removed are organic matter, especially phenols, thiocyanate and ammonium nitrogen. The concentrations of the main pollutants in the wastewater during the study ranged between 922 and $1980 \mathrm{mg} \mathrm{COD} / \mathrm{L}, 133$ and $293 \mathrm{mg}$ phenol/L, 176 and $362 \mathrm{mg} \mathrm{SCN} / \mathrm{L}$ and 123 and $296 \mathrm{mg} \mathrm{NH}_{4}{ }^{+}-\mathrm{N} / \mathrm{L}$. The biodegradation of these pollutants was studied employing different hydraulic residence times (HRT) and final effluent recycling ratios in order to minimize inhibition phenomena attributable to the high concentrations of pollutants. During the optimisation of the operating conditions, the removal of COD, phenols and thiocyanate was carried out in the first reactor and the nitrification of ammonium took place in the second. The best results were obtained when operating at an HRT of $98 \mathrm{~h}$ in the first reactor and $86 \mathrm{~h}$ in the second reactor, employing a recycling ratio of 2. The maximum removal efficiencies obtained were 90.7, 98.9, 98.6 and $99.9 \%$ for COD, phenols, thiocyanate and $\mathrm{NH}_{4}{ }^{+}-\mathrm{N}$, respectively. In order to remove nitrate, an additional reactor was also implemented to carry out the denitrification process, adding methanol as an external carbon source. Very high removal efficiencies (up to $99.2 \%$ ) were achieved.
\end{abstract}

(c) 2006 Published by Elsevier B.V.

Keywords: Coke wastewater; Phenol; Ammonium; Thiocyanate; Activated sludge; Nitrification; Denitrification

\section{Introduction}

Coke wastewater is a complex industrial wastewater present in many steel production facilities that originates from the process of destructive distillation of coal at high temperatures $\left(900-100^{\circ} \mathrm{C}\right.$ ) in the absence of air. The coal breaks down, giving rise to gases, liquid and solid organic compounds of low molecular weight and a non-volatile carbonaceous residue known as coke.

The substances exiting the coke ovens as liquids under ambient conditions undergo further processing so as to obtain byproducts such as ammonium sulphate, the resulting wastewater from these processes constituting coke wastewater, which contains considerable amounts of toxic compounds such as $\mathrm{CN}^{-}$, $\mathrm{SCN}^{-}$and phenols [1-3].

Phenol is a highly toxic organic compound even at low concentrations and its presence in aqueous media is severely

\footnotetext{
* Corresponding author. Tel.: +34 985182027; fax: +34 985182337.

E-mail address: emara@uniovi.es (E. Marañón).
}

restricted by current legislation. Coke wastewater also contains high concentrations of ammonium salts, thiocyanates and chlorides, though low concentrations of heavy metals, and very low levels of phosphorus [4,5]. The individual concentrations of each pollutant vary due to the different types of coal and conditions used in the coking process.

In a biological nitrification process, the autotrophic microorganisms that oxidize the $\mathrm{NH}_{4}{ }^{+}-\mathrm{N}$ are normally sensitive to the presence of certain chemical substances such as phenols [6]. However, this sensitivity can be overcome by decreasing the effective concentration of the inhibiting compounds by means of adsorption, precipitation, quelation and biodegradation. Nitrifying microorganisms may also develop a tolerance to the inhibitors. Other compounds contained in coke wastewater that have a toxic effect on oxidizing bacteria, both autotrophic and heterotrophic, are $\mathrm{CN}^{-}$(at concentrations higher than $50 \mathrm{mg} / \mathrm{L}$ ), $\mathrm{SCN}^{-}$and $\mathrm{NH}_{4}{ }^{+}-\mathrm{N}$ itself at high concentrations [7]. Similarly, biological degradation of $\mathrm{SCN}^{-}$is also affected by the presence of compounds such as $\mathrm{NH}_{4}{ }^{+}-\mathrm{N}$, phenols, $\mathrm{NO}_{2}{ }^{-}$and $\mathrm{NO}_{3}{ }^{-}$[8].

The complexity of coke wastewater resulting from the presence of a great variety of pollutants that may be removed biolog- 
ically but which are also toxic for the microorganisms that carry out their degradation make it necessary to conduct an in-depth study of the biological treatment of these pollutants in order to optimize the process.

This paper presents a study of the biological treatment of coke wastewater that forms part of a European project whose general aim is to study biological processes for treating wastewater from the steel industry. The present study focuses on coke wastewater, since at the time of carrying out the study, no biological treatment plant for this type of wastewater existed in Spain, though a number of industrial plants were in operation in other countries. In Zentralkokerie Saar, Dillingen (Germany), the process has two biological steps: the first includes denitrification and removal of organic matter and is carried out in separate tanks; nitrification takes place in the second step. In other existing plants, such as those in Kaiserstuhl (Germany), Serémage (France) and Sidmar (Belgium), a prior sedimentation step is followed by a biological treatment (combination of aerobic and anoxic tanks) and sludge settling and treatment. The main differences among these plants are the aeration system (pure oxygen or air), the type of coagulant, the concentration of excess sludge and the use or not of dilution water.

The removal of organic matter, phenols, $\mathrm{SCN}^{-}$and $\mathrm{NH}_{4}{ }^{+}-\mathrm{N}$ in a one-step activated sludge system was previously studied and the results are pending publication. Phenol removal efficiencies were always higher than $90 \%$ even for an HRT of $17.6 \mathrm{~h}$ and COD removals of up to $75 \%$ were obtained. Biodegradation of $\mathrm{SCN}^{-}$ and nitrification varied depending on the addition of bicarbonate to the system (as the alkalinity of the coke wastewater employed in the study was very low). A maximum removal of $90 \%$ was achieved for $\mathrm{SCN}^{-}$working at very high HRT $(167 \mathrm{~h})$ and of $71 \%$ for $\mathrm{NH}_{4}{ }^{+}-\mathrm{N}$ for an HRT of $54.3 \mathrm{~h}$.

Although it is possible to remove a major part of the pollutants contained in the wastewater using a single-step process, the concentrations obtained in the effluent are not low enough for disposal. In the present paper, a potential solution to obtain higher removal efficiencies involving a two-step process is studied. Organic matter and $\mathrm{SCN}^{-}$are removed in the first step and nitrification is performed in a second. In order to complete the removal of nitrogen compounds, a series of denitrification experiments were carried out in an additional step.

\section{Materials and methods}

The wastewater from a coke plant previously underwent a stripping treatment with $\mathrm{NaOH}$ to maintain $\mathrm{NH}_{4}{ }^{+}-\mathrm{N}$ concentrations at values of around $200 \mathrm{mg} / \mathrm{L}$. The wastewater was stored in a $200 \mathrm{~L}$ tank to which sulphuric acid was added to decrease $\mathrm{pH}$, along with $\mathrm{Na}_{2} \mathrm{HPO}_{4}$ as a source of phosphorous $\left(130 \mathrm{~g} / \mathrm{m}^{3}\right)$, $\mathrm{Al}_{2}\left(\mathrm{SO}_{4}\right)_{3}$ to facilitate clarification of the effluent $\left(10 \mathrm{~g} / \mathrm{m}^{3}\right)$ and a small amount of antifoaming agent (NALCO 71D5). Start-up of the reactors was carried out using sludge from the leachate treatment plant at the Central Landfill for Municipal Solid Waste of Asturias (COGERSA).

The wastewater was pumped by means of an Ismatec Ecoline pump model ISM 834A into a $17 \mathrm{~L}$ volume activated sludge tank. The mixed liquor from this first reactor passed into a settling tank by gravity, the sludge being recycled to the reactor with a recycling ratio $\left(R=Q_{\mathrm{R}} / Q\right)$ of 1 by means of an Ismatec Ecoline pump model VC-280. The clarified effluent (effluent 1) from the first settling tank was fed by gravity into a second aerated tank of $15 \mathrm{~L}$ volume in which nitrification took place. As the wastewater presents very low alkalinity values, a dosage of sodium bicarbonate that varied between 0.84 and $1.4 \mathrm{~kg} / \mathrm{m}^{3}$ depending on the ammonium concentration was added to this reactor as a source of carbon in order to favour the growth of autotrophic microorganisms. The amount added is in accordance with a consumption of $6.5 \mathrm{kgCaCO}_{3} / \mathrm{kgNH}_{4}{ }^{+}-\mathrm{N}$, found to be the optimum in a previous study [9]. The mixed liquor from the second aerated reactor passed by gravity into a second settling tank in which the sludge was separated and recycled to the reactor by means of an Ismatec pump model VC-380 with $R=1$, obtaining a final clarified effluent (effluent 2).

From Day 261 onwards, the final effluent was recycled to the first reactor by an Ismatec pump model ISM 834A with the aim of decreasing the concentration of $\mathrm{NH}_{4}{ }^{+}-\mathrm{N}$ in the reactor and of favouring the biodegradation of $\mathrm{SCN}^{-}$(as the presence of a higher ammonium concentration was found to decrease $\mathrm{SCN}^{-}$ removal efficiency) [9]. Different recycling ratios $(R=1-3)$ were employed to determine the optimum value.

The $\mathrm{pH}$ of the first reactor was kept around 6-6.5, found to be the optimum value for the biodegradation of thiocyanates in a previous study [9], in agreement with other researchers [8]. The second reactor was operated at a $\mathrm{pH}$ of 8-8.5 to favour nitrification. The temperature of both reactors was kept constant at a value of $35 \pm 0.5^{\circ} \mathrm{C}$ by means of a heating element. This temperature was chosen due to the fact that the temperature of coke wastewater at the steel works usually varied between 35 and $45^{\circ} \mathrm{C}_{\overline{\bar{\lambda}}}$ Moreover, as is well known, mesophilic microorganisms operate in the range $10-35^{\circ} \mathrm{C}$, the reaction kinetics increasing with temperature.

The volatile suspended solids in the mixed liquors represented an average percentage value of $75 \%$ of total suspended solids and ranged between 2.0 and $3.0 \mathrm{~g} / \mathrm{L}$. The sludge generally presented good settling conditions throughout the entire operation (Sludge Volume Index, SVI, lower than $100 \mathrm{~mL} / \mathrm{g}$ ). The oxygen concentration in the reactors was always kept above $3 \mathrm{mg} / \mathrm{L}$.

Different volumetric flow rates were employed and thus different hydraulic retention times (HRT). Table 1 shows the different HRT employed and the average concentrations of pollutants during the different steps of the study. Due to variations in the composition of the coke wastewater, it was very difficult to maintain a fixed value for the organic loading rate (OLR) and for the nitrogen loading rate (NLR), and so the chosen operating parameter was the HRT. Table 2 shows the values of OLR, NLR and food to microorganisms ratios $(\mathrm{F} / \mathrm{M})$ for the different working conditions.

The study of the final denitrification stage commenced once the two-step process was operating steadily, with HRT of 96 and $86 \mathrm{~h}$ in the first and the second reactor, respectively, and an effluent recycling ratio of 2 . The final effluent from the two-step 
Table 1

Average composition of coke wastewater under different working conditions

\begin{tabular}{|c|c|c|c|c|c|c|c|}
\hline $\mathrm{HRT}_{1}(\mathrm{~h})$ & $\mathrm{HRT}_{2}(\mathrm{~h})$ & $R$ & $\mathrm{pH}^{\mathrm{a}}$ & $\mathrm{COD}\left(\mathrm{mg} \mathrm{O}_{2} / \mathrm{L}\right)$ & $\mathrm{SCN}^{-}(\mathrm{mg} / \mathrm{L})$ & $\mathrm{NH}_{4}{ }^{+}-\mathrm{N}(\mathrm{mg} / \mathrm{L})$ & Phenols (mg/L) \\
\hline 27.8 & 20.3 & 0 & 6.9 & 1539 & 316 & 193 & 264 \\
\hline 42.4 & 31 & 0 & 6.7 & 1454 & 298 & 204 & 255 \\
\hline 61 & 44.6 & 0 & 5.8 & 1197 & 234 & 186 & 194 \\
\hline 98 & 86 & 0 & 5.3 & 1175 & 266 & 233 & 237 \\
\hline 98 & 86 & 1 & 2.6 & 1187 & 215 & 194 & 187 \\
\hline 98 & 86 & 2 & 2.2 & 1361 & 277 & 206 & 221 \\
\hline 98 & 86 & 3 & 2.2 & 1609 & 326 & 180 & 193 \\
\hline
\end{tabular}

a These values are obtained after the addition of $98 \% \mathrm{H}_{2} \mathrm{SO}_{4}$ (initial $\mathrm{pH}$ values: $8.1-8.8$ ).

process was fed into a $10 \mathrm{~L}$ volume reactor. The study lasted 156 days, employing different HRT (86.4, 61.7 and 43.2 h), SRT (71, 52 and 37 days) and F/M ratios $(0.17,0.30$ and $0.44 \mathrm{kgNO}_{3}-/ \mathrm{kgSSV} /$ day). The oxygen concentration in the denitrification reactor was kept around $0.16 \mathrm{mg} / \mathrm{L}$ to maintain the anoxic conditions required for the denitrification process [10].

The $\mathrm{pH}$ inside the denitrification tank was kept between 8.3 and 8.5 [11]. The average concentration of total suspended solids (TSS) in the denitrification reactor was $3.0 \mathrm{~g} / \mathrm{L}, 78 \%$ being volatile suspended solids (VSS).

With the aim of monitoring the biodegradation process taking place inside the reactors, the influent and the effluents were analysed using standard methods [12]. In the case of not being able to carry out immediate analyses, the samples were always kept under refrigeration at $4{ }^{\circ} \mathrm{C}$. Phenols, COD and nitrates were analysed by colorimetric methods using a HACH DR/2010 Spectrophotometer. $\mathrm{NH}_{4}{ }^{+}-\mathrm{N}$ concentration was measured by potentiometry using an Orion 95-12 BN ion selective electrode. $\mathrm{SCN}^{-}$was analysed by means of a colorimetric method based on the formation at an acid $\mathrm{pH}$ of an intense red complex between $\mathrm{Fe}^{+3}$ and $\mathrm{SCN}^{-}$.

\section{Results and discussion}

\subsection{Removal of thiocyanate}

Fig. 1 shows the concentration of $\mathrm{SCN}^{-}$in the influent and effluents from both reactors, as well as the total removal efficiency obtained throughout the study. Removal efficiencies higher than $90 \%$ were obtained for a recycling ratio of 2 , the maximum being $98.7 \%$. Very low $\mathrm{SCN}^{-}$concentrations in the effluent were likewise achieved (minimum value: $4 \mathrm{mg} / \mathrm{L}$ ). An important decrease in removal was observed when the recycling ratio was increased to 3 . This ratio gave rise to hydrodynamic problems in the reactors and system instability, resulting in final $\mathrm{SCN}^{-}$concentrations of up to $81 \mathrm{mg} / \mathrm{L}$.

Note should be taken that $\mathrm{SCN}^{-}$removal occurred in both reactors, since its biodegradation may take place via different mechanisms [8,13]. According to Kim and Katayama [14], Thiobacillus thioparus oxidizes thiocyanate as an energy and nitrogen source to $\mathrm{CO}_{2}, \mathrm{NH}_{3}$ and $\mathrm{SO}_{4}{ }^{-2}$ during autotrophic growth. Likewise, several heterotrophic bacteria degrade thiocyanate during their growth and use the released ammonia as a source of nitrogen $[15,16]$.

Table 2

Average COD and $\mathrm{NH}_{4}{ }^{+}-\mathrm{N}$ removals under different working conditions

\begin{tabular}{|c|c|c|c|c|c|c|}
\hline SRT & HRT & $R$ & $\mathrm{kgCOD} / \mathrm{m}^{3} \mathrm{~d}$ & VSS (g/L) & kgCOD/kgVSS/day & COD removal $(\%)$ \\
\hline \multicolumn{7}{|c|}{ Reactor 1} \\
\hline 38 & 27.8 & 0 & 1.33 & 3.0 & 0.41 & 45.5 \\
\hline 42 & 42.4 & 0 & 0.82 & 2.6 & 0.31 & 68.6 \\
\hline 47 & 61 & 0 & 0.48 & 2.0 & 0.26 & 77.6 \\
\hline 76 & 98 & 0 & 0.29 & 2.1 & 0.13 & 65.9 \\
\hline 76 & 98 & 1 & 0.35 & 2.5 & 0.13 & 79.6 \\
\hline 93 & 98 & 2 & 0.42 & 2.8 & 0.13 & 86.2 \\
\hline 100 & 98 & 3 & 0.78 & 2.6 & 0.15 & 74.9 \\
\hline SRT & HRT & $R$ & $\mathrm{kgNH}_{4}{ }^{+}-\mathrm{N} / \mathrm{m}^{3} \mathrm{~d}$ & VSS (g/L) & $\mathrm{kgNH}_{4}{ }^{+}-\mathrm{N} / \mathrm{kgVSS} /$ day & $\mathrm{NH}_{4}{ }^{+}-\mathrm{N}$ removal $(\%)$ \\
\hline \multicolumn{7}{|c|}{ Reactor 2} \\
\hline 32 & 20.3 & 0 & 0.14 & 3.0 & 0.04 & 65.6 \\
\hline 32 & 31 & 0 & 0.08 & 2.2 & 0.03 & 67.1 \\
\hline 32 & 44.6 & 0 & 0.10 & 1.5 & 0.05 & 34.7 \\
\hline 52 & 86 & 0 & 0.09 & 1.9 & 0.03 & 99.0 \\
\hline 64 & 86 & 1 & 0.04 & 2.1 & 0.02 & 97.6 \\
\hline 73 & 86 & 2 & 0.02 & 1.9 & 0.01 & 99.3 \\
\hline 54 & 86 & 3 & 0.05 & 2.2 & 0.01 & 32.4 \\
\hline
\end{tabular}



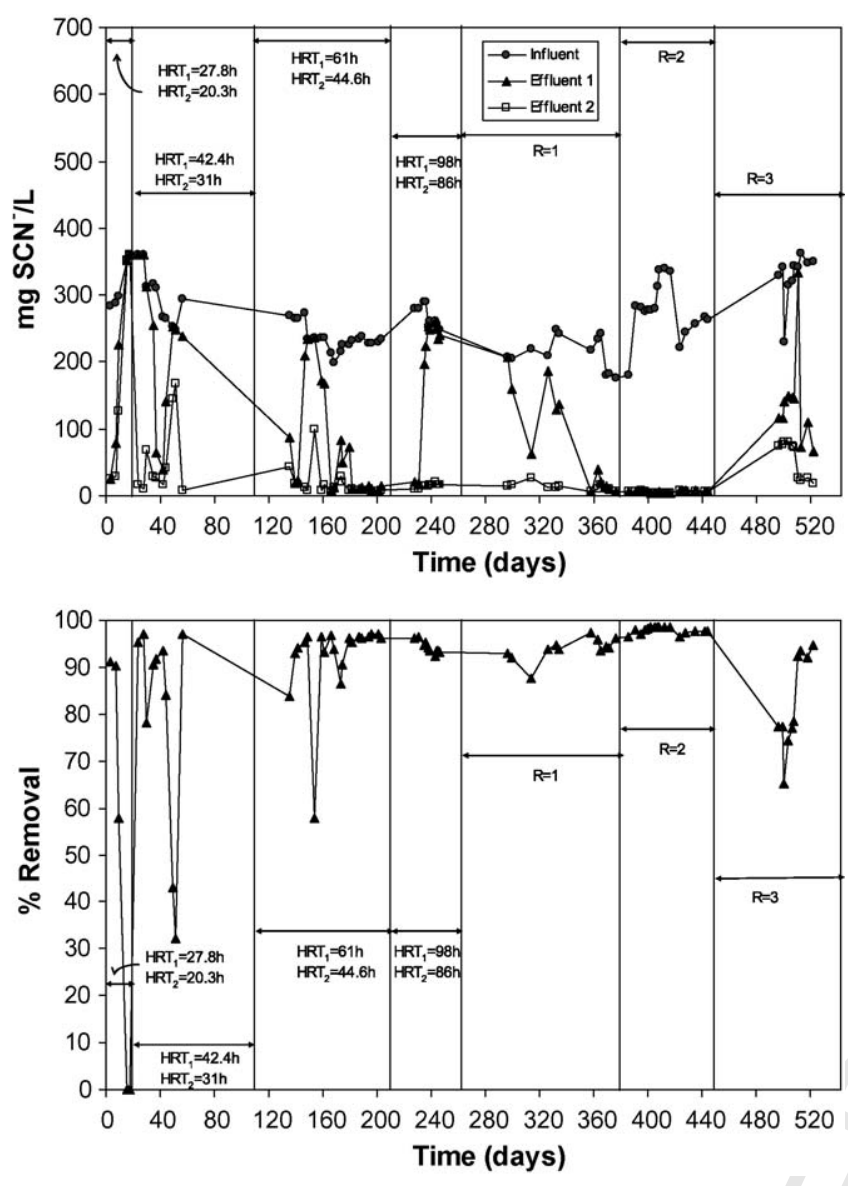

Fig. 1. $\mathrm{SCN}^{-}$evolution in the influent and effluents and total removal efficiencies obtained in the biological treatment of coke wastewater.

Recycling of the effluent favoured the biodegradation of $\mathrm{SCN}^{-}$in the first reactor, as it leads to a decrease in $\mathrm{NH}_{4}{ }^{+}-\mathrm{N}$ concentration. The biodegradation of $\mathrm{SCN}^{-}$may be influenced by the presence of other compounds such a $\mathrm{NH}_{4}{ }^{+}-\mathrm{N}$, phenols, nitrates or nitrites [7,8]. To evaluate this influence, the effect of $\mathrm{NH}_{4}{ }^{+}-\mathrm{N}$ concentration on $\mathrm{SCN}^{-}$removal was studied for an HRT of $98 \mathrm{~h}$ and different recycling ratios. The ammonia concentration in the first reactor is plotted against removed $\mathrm{SCN}^{-}$ in Fig. 2. The experimental data can be fitted $(r=0.994)$ to a theoretical curve according to the following equation:

$\% \mathrm{SCN}^{-}=100+15.1 \times\left(1-\mathrm{e}^{0.0056 \times\left[\mathrm{N}^{-} \mathrm{NH}_{4}^{+}\right]}\right)$

According to this curve, employing an HRT of $98 \mathrm{~h}$, removal efficiencies of $\mathrm{SCN}^{-}$higher than $98 \%$ are obtained when $\mathrm{NH}_{4}{ }^{+}-\mathrm{N}$ concentrations are lower than $23 \mathrm{mg} / \mathrm{L}$. If the $\mathrm{NH}_{4}{ }^{+}-\mathrm{N}$ concentration increases above $260 \mathrm{mg} / \mathrm{L}$, however, the efficiency will fall below 50\%. Other authors [8] found that ammonium nitrogen presents a slightly inhibitory effect on thiocyanate degradation for concentrations higher than $3 \mathrm{~g} / \mathrm{L}$. However, these authors employed synthetic wastewaters in their studies. Industrial coke wastewater may present a greater complexity owing to the presence of different types of toxic pollutants.

The removal of $\mathrm{SCN}^{-}$in the first reactor by heterotrophic bacteria is a relevant factor for the subsequent correct function-

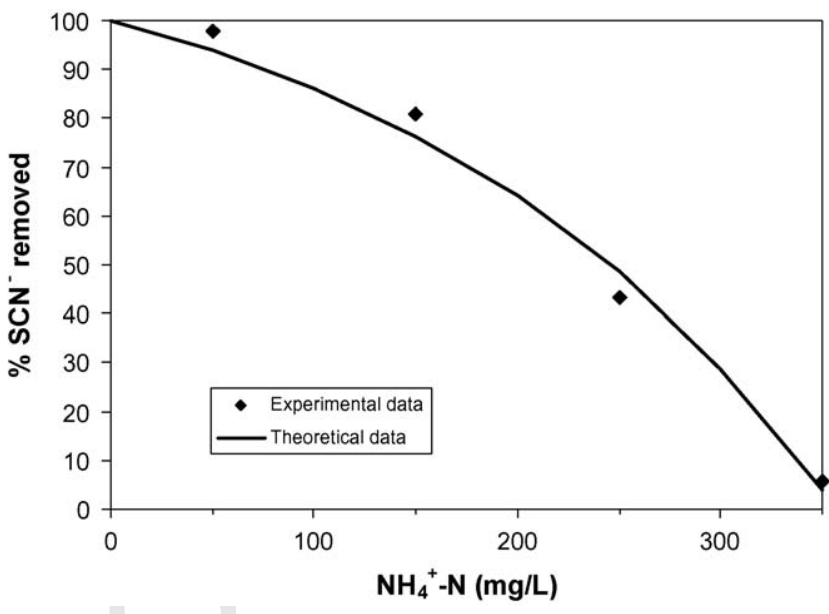

Fig. 2. $\mathrm{NH}_{4}{ }^{+}-\mathrm{N}$ influence on $\mathrm{SCN}^{-}$biodegradation for an $\mathrm{HRT}$ of $98 \mathrm{~h}$.

ing of the nitrification process in order to avoid inhibitory effects $\quad 236$ in the nitrifying bacteria [9].

\subsection{Removal of $C O D$}

Fig. 3 shows the COD concentration in the process influent and effluents as well as total removal efficiencies. COD removals

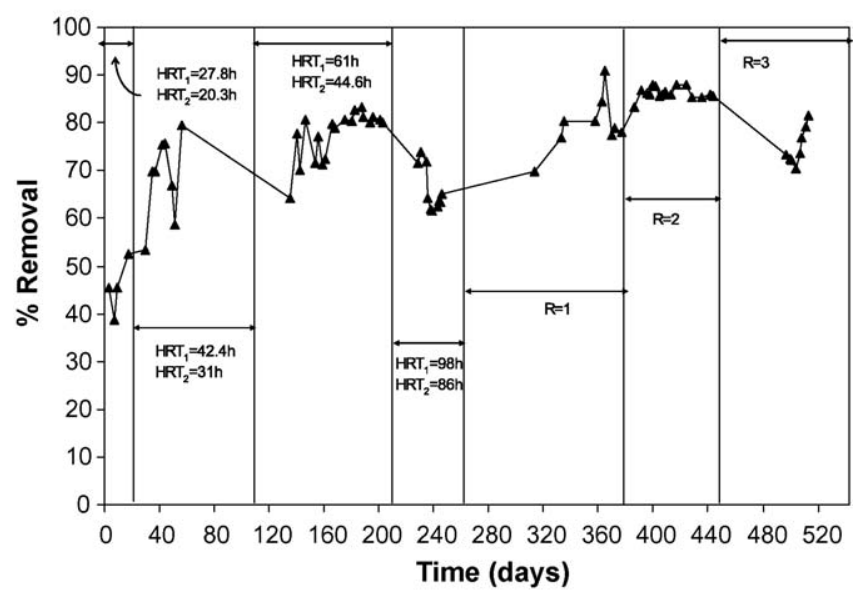

Fig. 3. COD evolution in the influent and effluents and total removal efficiencies obtained in the biological treatment of coke wastewater. 
of around $80 \%$ were obtained for an $\mathrm{HRT}_{1}$ of $61 \mathrm{~h}$, increasing to around $90 \%$ when the effluent was recycled, except for a recycling ratio of 3 , for the aforementioned reason.

Apart for the first few days of operation, in which the system was not steady, the concentration in the effluent from Reactor 1 was very similar to that from Reactor 2, which means that the COD is almost totally removed in the first step. The lower COD concentration obtained in the final effluent was $159 \mathrm{mg} / \mathrm{L}$ for an $\mathrm{HRT}_{1}=96 \mathrm{~h}$ and $R=2$.

As can be seen in Table 2, except for the lowest HRT employed $\left(\mathrm{OLR}=1.3 \mathrm{kgCOD} / \mathrm{m}^{3} \mathrm{~d}\right)$, the average COD removals were always $\geq 70 \%$ under the different working conditions (OLR from 0.3 to $0.8 \mathrm{kgCOD} / \mathrm{m}^{3} \mathrm{~d}$. and $\mathrm{F} / \mathrm{M}$ ratios from 0.13 to $0.31 \mathrm{kgCD} / \mathrm{kgVSS} /$ day.

\subsection{Removal of phenols}

The concentration of phenols in the final effluent varied between $2.3 \mathrm{mg} / \mathrm{L}$ for $R=2$ and $16 \mathrm{mg} / \mathrm{L}$ for $R=3$, being very similar to that obtained in effluent 1 . This means that phenols are also mainly removed in the first reactor (Fig. 4). Very high total removal efficiencies $(\geq 95 \%)$ were obtained under all the conditions employed, values higher than $98 \%$ being obtained for a recycling ratio of 2 . Removal decreased slightly when operating at $R=3$, due to the aforementioned problems of instability.
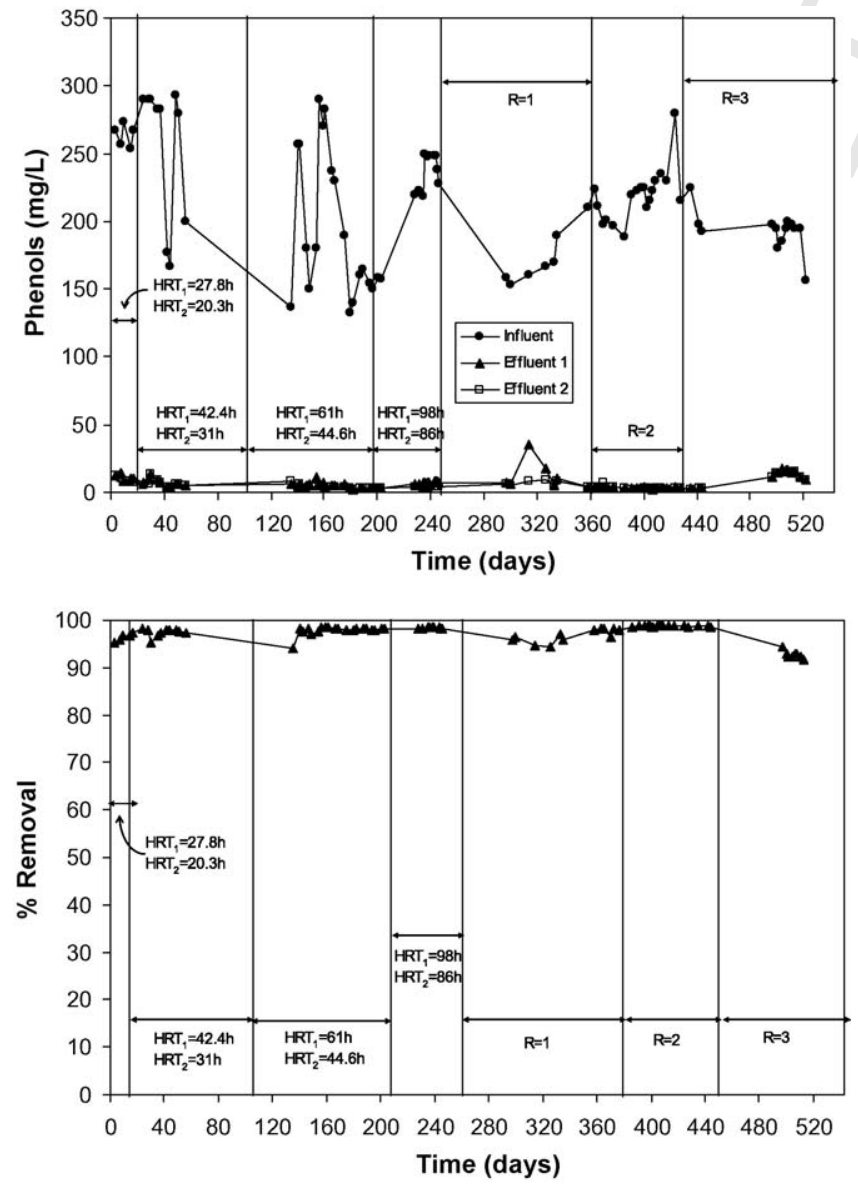

Fig. 4. Phenols evolution in the influent and effluents and total removal efficiencies obtained in the biological treatment of coke wastewater.

\subsection{Removal of $\mathrm{NH}_{4}^{+}-\mathrm{N}$}

264

One of the aims of the two-step process was to remove $\mathrm{NH}_{4}{ }^{+}-\mathrm{N}$ in a second reactor once the major part of COD, phenols and $\mathrm{SCN}^{-}$had been removed in the first step. Autotrophic nitrifying microorganisms need to have a certain available alkalinity. With an average alkalinity value in the wastewater of $0.25 \mathrm{gCaCO}_{3} / \mathrm{L}$ and for an initial $\mathrm{NH}_{4}{ }^{+}-\mathrm{N}$ concentration of around $200 \mathrm{mg} / \mathrm{L}$, the ratio $\mathrm{kgCaCO}_{3} / \mathrm{kgNH}_{4}{ }^{+}-\mathrm{N}$ is 1.25 , a clearly low value $[10,17]$. In a previous study, a value of $6.5 \mathrm{kgCaCO}_{3} / \mathrm{kgNH}_{4}{ }^{+}-\mathrm{N}$ was found to be the optimum for $\mathrm{NH}_{4}{ }^{+}-\mathrm{N}$ removal in this coke wastewater [9]. Therefore, alkalinity was added throughout the entire study to the nitrification reactor in the form of sodium bicarbonate.

Fig. 5 shows the variation in $\mathrm{NH}_{4}{ }^{+}-\mathrm{N}$ concentration in the influent and effluents as well as the total removal obtained via nitrification. The ammonia concentration in the influent ranged between 123 and $296 \mathrm{mg} / \mathrm{L}$. Throughout the first part of the experiment (from Day 1 to 140), effluent 1 presented lower $\mathrm{NH}_{4}{ }^{+}-\mathrm{N}$ concentrations than the influent, which means that nitrification was partially taking place in the first reactor. This could be the result of poor control of $\mathrm{pH}$ during that period (average $\mathrm{pH} 8.5$ in the first reactor), since $\mathrm{pH}$ values of between 7.8 and 8.9 favour the nitrification process [18,19]. From Day 150 to 240, operating at higher HRT but without recycling of the final
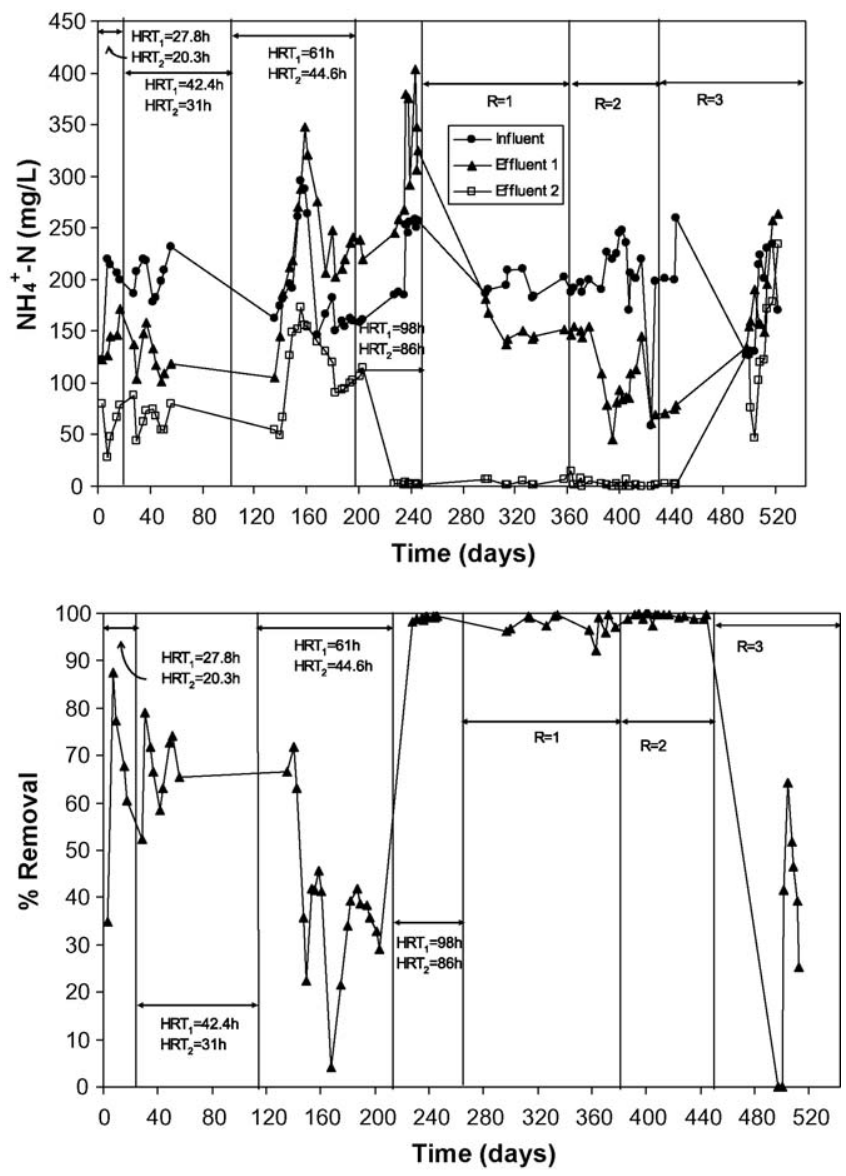

Fig. 5. $\mathrm{NH}_{4}{ }^{+}-\mathrm{N}$ evolution in the influent and effluents and total removal efficiencies obtained in the biological treatment of coke wastewater. 


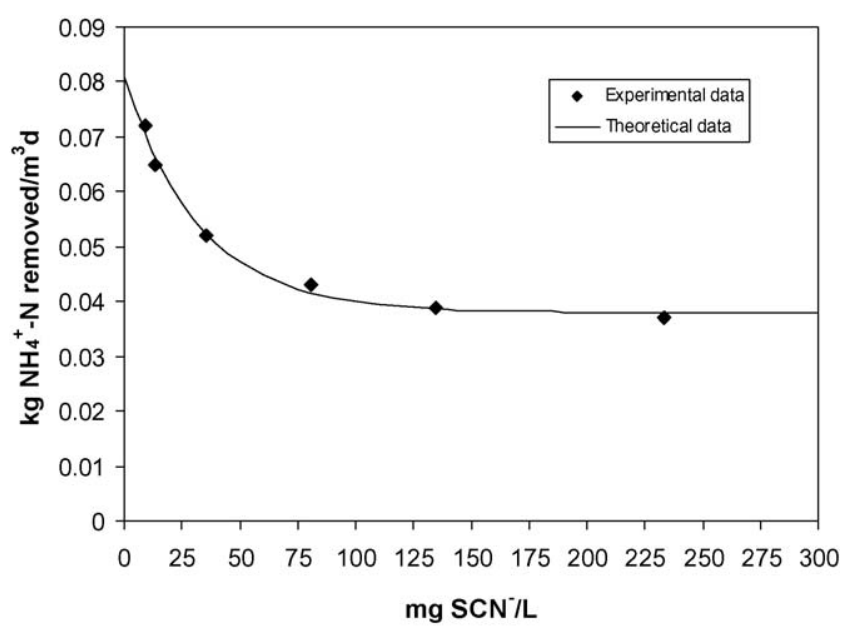

Fig. 6. Influence of $\mathrm{SCN}^{-}$on removed $\mathrm{NH}_{4}{ }^{+}-\mathrm{N}$ loading rate in the nitrification reactor for an HRT of $44.6 \mathrm{~h}$.

effluent, the ammonia concentration increased in the first reactor. This may be due to both the transformation of organic nitrogen into $\mathrm{NH}_{4}^{+}-\mathrm{N}$ and the biodegradation of $\mathrm{SCN}^{-}$into $\mathrm{NH}_{4}{ }^{+}, \mathrm{CO}_{2}$ and $\mathrm{SO}_{4}{ }^{2-}[7,8,13]$.

The highest ammonium removal (99\%) was obtained when operating at an $\mathrm{HRT}_{2}$ of $86 \mathrm{~h}$ and a recycling ratio of 2 (minimum effluent concentration of $0.12 \mathrm{mgNH}_{4}{ }^{+}-\mathrm{N} / \mathrm{L}$ ), although very high removals were also obtained for the same HRT without recycling of the final effluent. As occurs with the other pollutants, a recycling ratio of 3 gave rise to a decrease in removal efficiency. Table 2 shows the average removals obtained under the different working conditions. For an SRT of 32 days, an increase in the nitrification efficiency was not observed when increasing the HRT. With respect to the specific loading rate, values higher than $0.04 \mathrm{kgNH}_{4}{ }^{+}-\mathrm{N} / \mathrm{kgVSS} /$ day led to a decrease in nitrification. A marked increase in nitrification was observed for an SRT of 52 days and an HRT of $98 \mathrm{~h}$. Under these working conditions, the presence of thiocyanate does not seem to have a notable influence on nitrification. When the recirculation ratio was increased from 2 to 3 , removal decreased from 99 to $32 \%$ due to hydrodynamic problems.

To study the influence of $\mathrm{SCN}^{-}$on nitrification when operating at low HRT, experiments were carried out with coke wastewater containing different concentrations of SCN for an HRT of 44.6 h. The experimental results, shown in Fig. 6, were fitted to an exponential curve $(r=0.997)$ according to the following equation:

$N=0.081-\left\{0.043 \times\left(1-\mathrm{e}^{-0.031\left[\mathrm{SCN}^{-}\right]}\right)\right\}$ where $N$ is the volumetric nitrification rate $\left(\mathrm{kg} \mathrm{NH}_{4}{ }^{+}-\mathrm{N}\right.$ removed $/ \mathrm{m}^{3} /$ day).

According to the theoretical curve, in the absence of $\mathrm{SCN}^{-}$, $0.081 \mathrm{kgNH}_{4}{ }^{+}-\mathrm{N} / \mathrm{m}^{3} /$ day could be removed, whereas for $\mathrm{SCN}^{-}$ concentrations higher than $150 \mathrm{mg} / \mathrm{L}$, the denitrification rate decreases to $0.037 \mathrm{kgNH}_{4}{ }^{+}-\mathrm{N} / \mathrm{m}^{3} /$ day.

To evaluate whether the nitrification process functions correctly, measurement of the $\mathrm{NH}_{4}{ }^{+}-\mathrm{N}$ concentration alone would be insufficient, since this does not confirm that the final product obtained is $\mathrm{NO}_{3}{ }^{-}$. In some cases, the final transformation of $\mathrm{NO}_{2}{ }^{-}$to $\mathrm{NO}_{3}{ }^{-}$in the final nitrification step may be inhibited, especially when the concentration of dissolved oxygen in the mixed liquor is lower than $2 \mathrm{mg} / \mathrm{L}$ or when SRT lower than 15 days are employed [20,21].

Throughout this study, the concentration of both compounds was measured regularly, no $\mathrm{NO}_{2}{ }^{-}$being detected, the $\mathrm{NO}_{3}{ }^{-}$ concentration ranging between 282 and $428 \mathrm{mgNO}_{3}{ }^{-}-\mathrm{N} / \mathrm{L}$.

In order to remove the nitrate formed in the nitrification process, the effluent from the two-step process was treated in a third reactor of $10 \mathrm{~L}$ volume. Table 3 shows the average concentrations of the different pollutants in the effluent entering the denitrification reactor for the different HRT employed. The concentrations of COD, phenols and $\mathrm{SCN}^{-}$fed into the denitrification reactor were very low, since these pollutants had already been removed in the previous steps. COD values ranged between 165 and $220 \mathrm{mg} / \mathrm{L}$ and therefore, as denitrifying microorganisms are heterotrophic, methanol was added in this study as an external organic carbon source.

The methanol dosage employed was varied throughout the study so as to determine the optimum value that would give rise to maximum nitrate removal and would not increase the COD of the effluent. During the first 16 days, a ratio of $6.7 \mathrm{mgCOD} / \mathrm{mg}$ $\mathrm{NO}_{3}{ }^{-}-\mathrm{N}$ was used to favour heterotrophic growth. A high removal of nitrates was observed, although an important increase of the effluent COD also occurred (Figs. 7 and 8). Different ratios were subsequently assayed, ranging between 3 and $4 \mathrm{mgCOD} / \mathrm{mgNO}_{3}{ }^{-}-\mathrm{N}$. The optimum value was 3.5 , corresponding to a dosage of $1.2 \mathrm{~L}$ methanol $/ \mathrm{m}^{3}$. This value was subsequently used in the experiments from Day 48 onwards.

The nitrate loading rate varied between $0.09 \mathrm{kgNO}_{3}{ }^{-}-\mathrm{N} / \mathrm{m}^{3} /$ day for HRT of $86.4 \mathrm{~h}$ and $0.23 \mathrm{kgNO}_{3}{ }^{-}-\mathrm{N} / \mathrm{m}^{3} /$ day for $43.2 \mathrm{~h}$. Fig. 7 shows the evolution of the nitrate concentration in the influent and effluent of the denitrification process as well as the removal obtained for the different conditions employed. Influent concentrations ranged between 282 and $428 \mathrm{mg} \mathrm{NO}{ }_{3}{ }^{-}-\mathrm{N} / \mathrm{L}$ and effluent concentrations were lower than $0.12 \mathrm{mg} \mathrm{NO}_{3}{ }^{-}-\mathrm{N} / \mathrm{L}$. Removal

Table 3

Average characteristics of coke wastewater and the influent to the denitrification reactor during the three-step study

\begin{tabular}{|c|c|c|c|c|c|c|c|c|c|c|}
\hline \multirow[t]{2}{*}{$\mathrm{HRT}_{3}(\mathrm{~h})$} & \multicolumn{2}{|c|}{$\mathrm{COD}(\mathrm{mg} / \mathrm{L})$} & \multicolumn{2}{|c|}{ Phenols (mg/L) } & \multicolumn{2}{|c|}{$\mathrm{SCN}^{-}(\mathrm{mg} / \mathrm{L})$} & \multicolumn{2}{|c|}{$\mathrm{NH}_{4}{ }^{+}-\mathrm{N}(\mathrm{mg} / \mathrm{L})$} & \multicolumn{2}{|c|}{$\mathrm{NO}_{3}{ }^{-}-\mathrm{N}(\mathrm{mg} / \mathrm{L})$} \\
\hline & WW & $\mathrm{DN}$ & WW & $\mathrm{DN}$ & WW & $\mathrm{DN}$ & WW & $\mathrm{DN}$ & WW & DN \\
\hline 86.4 & 1312 & 220 & 210 & 4.4 & 234 & 10.9 & 196 & 5.6 & n.d. & 331 \\
\hline 61.7 & 1337 & 165 & 220 & 2.6 & 297 & 4.8 & 218 & 1.6 & n.d. & 412 \\
\hline 43.2 & 1400 & 175 & 221 & 2.7 & 272 & 6.0 & 197 & 1.3 & n.d. & 420 \\
\hline
\end{tabular}

n.d., not detected. 
Table 4

Average characteristics of the final effluent and removal obtained in the three-step biological treatment of coke wastewater under different working conditions

\begin{tabular}{|c|c|c|c|c|c|c|c|c|c|c|c|c|c|}
\hline \multirow[t]{2}{*}{$\mathrm{HRT}_{3}(\mathrm{~h})$} & \multirow{2}{*}{$\begin{array}{l}\text { SRT } \\
\text { (day) }\end{array}$} & \multirow{2}{*}{$\begin{array}{l}\mathrm{kgNO}_{3}{ }^{-}- \\
\mathrm{N} / \mathrm{m}^{3} / \text { day }\end{array}$} & \multirow{2}{*}{$\begin{array}{l}\mathrm{kgNO}_{3}{ }^{-} \mathrm{N} / \\
\mathrm{kgSSV} / \text { day }\end{array}$} & \multicolumn{2}{|c|}{$\mathrm{COD}(\mathrm{mg} / \mathrm{L})$} & \multicolumn{2}{|c|}{ Phenols (mg/L) } & \multicolumn{2}{|c|}{$\mathrm{SCN}(\mathrm{mg} / \mathrm{L})$} & \multicolumn{2}{|c|}{$\mathrm{NH}_{4}{ }^{+}-\mathrm{N}(\mathrm{mg} / \mathrm{L})$} & \multicolumn{2}{|c|}{ Total- $N(\mathrm{mg} / \mathrm{L})$} \\
\hline & & & & Effluent & $\%$ & Effluent & $\%$ & Effluent & $\%$ & Effluent & $\%$ & Effluent & $\%$ \\
\hline 86.4 & 71 & 0.07 & 0.04 & 306 & 75.4 & 4.4 & 97.8 & 10.9 & 95.3 & 5.6 & 97.1 & 16.4 & 95.3 \\
\hline 61.7 & 52 & 0.16 & 0.07 & 261 & 80.5 & 2.6 & 98.8 & 4.8 & 98.3 & 1.6 & 99.3 & 2.8 & 99.3 \\
\hline 43.2 & 37 & 0.24 & 0.10 & 251 & 82.0 & 2.7 & 98.7 & 6.0 & 97.7 & 1.3 & 99.2 & 2.9 & 99.2 \\
\hline
\end{tabular}

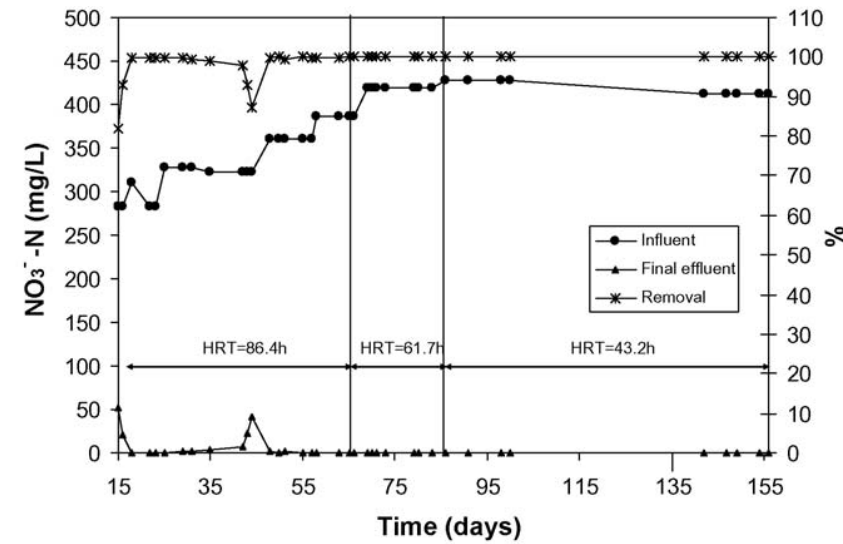

Fig. 7. $\mathrm{NO}_{3}{ }^{-}-\mathrm{N}$ evolution in influent and effluent and removal efficiency of the denitrification process.

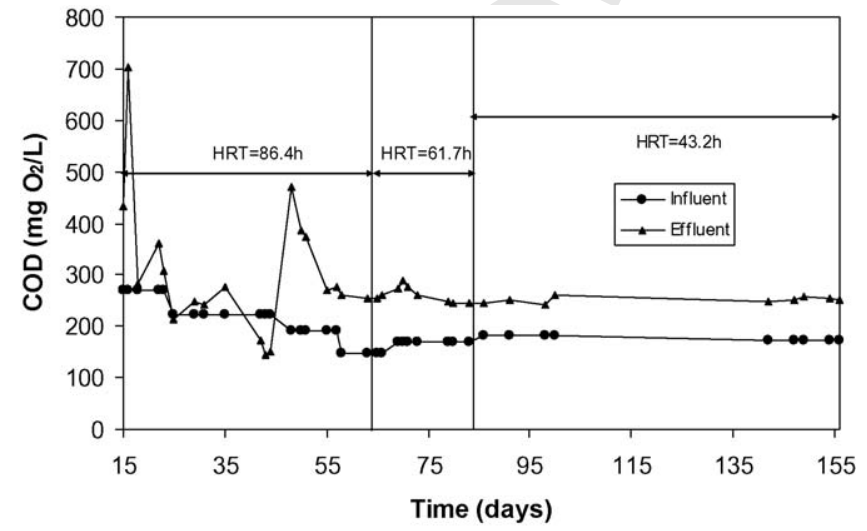

Fig. 8. COD evolution in the influent and effluent of the denitrification process.
The concentration of the rest of the pollutants did not experiment any change during this final step. Table 4 shows the average concentrations of the different pollutants in the final effluent as well as the average removal efficiencies obtained under the different working conditions employed in the three-step process. The lowest concentrations of pollutants obtained were $251 \mathrm{mg}$ $\mathrm{COD} / \mathrm{L}, 2.6 \mathrm{mg}$ phenols $/ \mathrm{L}, 4.8 \mathrm{mg} \mathrm{SCN}^{-} / \mathrm{L}, 1.3 \mathrm{mg} \mathrm{NH}_{4}{ }^{-}-\mathrm{N} / \mathrm{L}$ and $2.8 \mathrm{mg}$ Total-N/L.

\section{Conclusions}

The presence of $\mathrm{NH}_{4}{ }^{+}-\mathrm{N}$ influences the biodegradation of $\mathrm{SCN}^{-}$. Employing an HRT of $98 \mathrm{~h}$, no removals would be obtained for an ammonia concentration higher than $360 \mathrm{mg} / \mathrm{L}$. Likewise, the presence of $\mathrm{SCN}^{-}$influences the nitrification process, decreasing the nitrification rate from values of $0.08 \mathrm{kgNH}_{4}{ }^{+}-\mathrm{N} / \mathrm{m}^{3} /$ day in the absence of $\mathrm{SCN}^{-}$to $0.04 \mathrm{kgNH}_{4}{ }^{+}-\mathrm{N} / \mathrm{m}^{3} /$ day for $\mathrm{SCN}^{-}$concentrations between 125 and $230 \mathrm{mg} / \mathrm{L}$.

The biological treatment of coke wastewater in a two-step activated sludge system is favoured when an effluent recycling ratio of 2 is employed, obtaining average removal efficiencies of $86.2,98.8,97.9$ and $99.3 \%$ for COD, phenols, $\mathrm{SCN}^{-}$ and $\mathrm{NH}_{4}{ }^{+}-\mathrm{N}$, respectively, for a total HRT of $184 \mathrm{~h}(98 \mathrm{~h}$ in the first step and $86 \mathrm{~h}$ in the second). Under these conditions, the removal of $\mathrm{COD}$, phenols and $\mathrm{SCN}^{-}$takes place mainly in the first reactor, whereas nitrification occurs in the second. Recycling of the effluent leads to lower concentrations in the reactors and less inhibition phenomena between the microorganisms responsible for $\mathrm{SCN}^{-}$and $\mathrm{NH}_{4}{ }^{+}$biodegradation.

If denitrification is carried out as a third step, a methanol dosage of $1.2 \mathrm{~L} / \mathrm{m}^{3}$ (which represents a consumption of $3.5 \mathrm{mg}$ $\mathrm{COD} / \mathrm{mg} \mathrm{NO}_{3}{ }^{-}-\mathrm{N}$ ) must be added in order to achieve very high removal efficiencies (>99\%). A slight increase in the final effluent COD takes place (from 176 to $251 \mathrm{mg} \mathrm{O}_{2} / \mathrm{L}$ ) as a result of this addition of methanol.

\section{Acknowledgments}

The authors gratefully acknowledge the funding received from the European Union for the project "Advanced Process Control for Biological Water Treatment Plants in Steelworks", contract no. ECSC-7210-PR-235, and the Arcelor Group for their collaboration. They also wish to thank Mr. Paul Barnes for proof reading the English version of the manuscript. 


\section{References} 202.
[1] D. Bamelis, Biological purification of coking plant waters, La Revue de Metallurgie (February) (1992) 132-145.

[2] D. Jenkins, Towards a comprehensive model of activated sludge bulking and foaming, Water Sci. Technol. 25 (6) (1992) 215-2302.

[3] W. Keith, J. Antil, Biotreatment of coke oven effluent, Steel Time Internat. (1991) 26-35.

[4] J. Wanmmer, The implementation of bulking control in the design of activated sludge systems, Water Sci. Technol. 29 (7) (1994) 193-

[5] G.M. Wong-Chong, Retrofitting LTV coke plant wastewater treatment system to comply with treatment discharge limits, Iron Steel Eng. (October) (1994) 26-28.

[6] T. Yamagishi, J. Leite, S. Ueda, F. Yamaguchi, Simultaneous removal of phenol and ammonia by an activated sludge process with cross-flow filtration, Water Res. 13 (2001) 3089-3096.

[7] D.J. Richards, W.K. Shieh, Anoxic-oxic activated-sludge treatment of cyanides and phenols, Biotechnol. Bioeng. 33 (1989) 32-38.

[8] H.K. Kwon, S.H. Woo, J.M. Park, Thiocyanate degradation by Acremonium strictum and inhibition by secondary toxicants, Biotechnol. Lett. 24 (2002) 1347-1355.

[9] I. Vázquez, Study and modellization of the biological removal of pollutants in coke wastewaters (Estudio y modelización de la eliminación biológica de contaminantes en aguas de coquería). Ph.D. Thesis, University of Oviedo, 2005.

[10] N.H. Callado, E. Foresti, Removal of organic carbon, nitrogen and phosphorous in sequential batch reactors integrating the aerobic/anaerobic processes, Water Sci. Technol. 44 (4) (2001) 263273 .
[11] R.S. Ramalho, Tratamiento de aguas residuales, Editorial Reverté, S.A., 1996.

[12] APHA, AWWA, WPCF, Standard Methods for the Examination of Water and Wastewater, 17th ed., Public Health Association, Washington, DC, US, 1989.

[13] J. Stratford, A. Dias, C.H. Knowles, The utilization of thiocyanate as nitrogen source by heterotrophic bacterium: the degradative pathway involves formation of ammonia and tetrathionate, Microbiology 140 (1979) 2657-2672.

[14] S.J. Kim, Y. Katayama, Effect of growth conditions on thiocyanate degradation and emission of carbonyl sulfide by Thiobacillus thioparus THI115, Water Res. 34 (2000) 2887-2894.

[15] D.A. Stafford, A.G. Calley, The utilization of thiocyanate by a heterotrophic bacterium, J. Gen. Microbiol. 55 (1969) 285-289.

[16] P.M. Betts, D.F. Rinder, J.R. Fleeker, Thiocyanate utilisation by Arthobacter, Can. J. Microbiol. 25 (1979) 1277-1282.

[17] Y. Eum, E. Choi, Optimization of nitrogen removal from piggery waste by nitrite nitrification, Water Sci. Technol. 45 (12) (2002) 89-96.

[18] D. Kaplan, R. Wilhelm, A. Abeliovich, Interdepent environmental factors controlling nitrification in waters, Water Sci. Technol. 42 (1-2) (2000) $167-172$.

[19] G. Ruiz, D. Jeison, R. Chamy, Nitrification with high nitrite accumulation for the treatment of wastewater with high ammonia concentration, Water Res. 37 (2003) 1371-1377.

[20] J.L. Campos, J.M. Garrido-Fernández, R. Méndez, J.M. Lema, Nitrification at high ammonia loading rates in an activated sludge unit, Bioresour. Technol. 68 (1999) 141-148.

[21] A. Pollice, V. Tandoi, C. Lestingi, Influence of aeration and sludge retention time on ammonium oxidation to nitrite and nitrate, Water Res. 36 (2002) 2541-2546. 